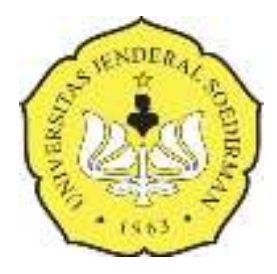

PAJU Volume 1 Nomor 12019

PHYSICAL ACTIVITY JOURNAL

http://jos.unsoed.ac.id/index.php/paju

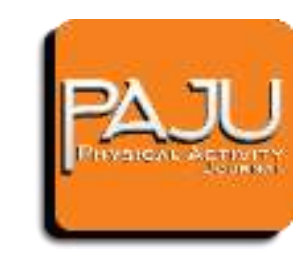

\title{
Pengaruh Umpan Balik Dan Motivasi Terhadap Shooting Dalam Permainan Sepakbola
}

\author{
Deni Pazriansyah ${ }^{1}$, Wildan Qohhar ${ }^{2}$ \\ 1,2 STKIP Situs Banten, Indonesia \\ email: deni.pazriansyah@stkipsitusbanten.ac.id¹, wildan.qohhar@stkipsitusbanten.ac.id² \\ DOI: https://doi.org/10.20884/1.paju.2019.1.1.2004
}

\begin{abstract}
Abstrak
Penelitian ini untuk memperoleh informasi dari pengaruh umpan balik dan motivasi terhadap teknik shooting dalam permainan sepakbola. Penelitian ini adalah dilakukan metode eksperimen dengan design factorial by level $2 \times 2$, pengujian analisis hipotesis penelitian ini dengan sample 56 siswa dengan menggunakan random sampling. Penelitian ini ada 3 aspek yg di fokuskan, umpan balik dan informasi untuk itu kemampuan dari teknik shooting dalam permainan sepakbola. Dari data kuisioner dapat di analisis dengan anava 2 jalur, dari hasil analisis tersebut dapat disimpulkan : 1) Terdapat perbedaan kemampuan shooting sepakbola antara siswa yang berlatih dengan menggunakan umpan balik secara langsung dengan umpan balik tertunda, 2) Terdapat pengaruh interaksi antara umpan balik langsung dan motivasi belajar terhadap kemampuan shooting sepakbola, 3) Terdapat perbedaan kemampuan shooting sepakbola siswa yang memiliki motivasi tinggi dengan pembelajaran yang menerapkan umpan balik langsung lebih tinggi dibandingkan umpan balik tertunda, 4) Terdapat Perbedaan kemampuan shooting sepakbola siswa yang memiliki motivasi rendah dengan pembelajaran yang menerapkan umpan balik langsung lebih tinggi dibandingkan umpan balik tertunda.
\end{abstract}

Kata kunci : kemampuan teknik shooting dalam sepakbola, umpan balik, motivasi

\begin{abstract}
The objective research is to obtain information concerning to the effect of feedback and motivation to the ability of shooting techniques of football students. The research was conducted by using experiment method with design factorial $2 \times 2$ analysis in testing hypothesis. In this research, 56 from 56 student's cluster random sampling. The research was focused on tree aspect; feedback and motivation to the ability of shooting techniques of football students. The data were colected with questionnaire and analyzed with anava two ways analysis. Result on the analyisis it is concluded that (1) the ability of shooting techniques of football students are given the direct feedback is higher than students who were given indirect feedback, (2) there is an interaction between feedback and motivation to shooting techniques of football students, (3) the ability of shooting techniques of football students in the group of students who have motivation high given direct feedbackis greater rather than a group of students were given indirect feedback, (4) the ability of shooting techniques of football students in the group of students who have motivation low given about indirect feedback is larger than the group of students were given about the direct feedback.
\end{abstract}

Keywords: The Ability Of Shooting Techniques Of Football, Feedback, Motivation

\begin{tabular}{llll}
\hline Alamat Koresponden & $:$ & Prodi PJKR STKIP Situs Banten & e-ISSN \\
E-mail & $:$ & deni.pazriansyah@stkipsitusbanten.ac.id & $: 2686-5807$ \\
No. Telp./Hp & $:$ & &
\end{tabular}




\section{PENDAHULUAN}

Pendidikan pada hakikatnya adalah sebuah proses sistematis dan terencana untuk mewujudkan dan mengaktifkan potensi orang lain agar yang bersangkutan memiliki pengetahuan luas, pengendalian diri, kepribadian, kecerdasan, akhlak mulia serta keterampilan yang diperlukan dirinya, masyarakat, bangsa dan negara. Proses penyelenggaraan pendidikan pada institusi pendidikan di negara kita berupaya untuk mewujudkan manusia yang beriman dan bertakwa kepada tuhan yang maha esa. Adanya upaya mewujudkan manusia sebagaimana telah tertuang dalam UU No. 20 Tahun 2003 tentang sistem Pendidikan Nasional Bab II Pasal III yang berbunyi : Pendidikan Nasional berfungsi mengembangkan kemampuan dan membentuk watak serta peradaban bangsa yang bermartabat dalam rangka mencerdaskan kehidupan berbangsa, bertujuan untuk berkembangnya potensi peserta didik agar menjadi manusia yang beriman dan bertaqwa kepada Tuhan yang Maha Esa, berahlak mulia, sehat, berilmu, cakap, kreatif, mandiri, dan menjadi warga negara yang demokratis serta bertanggung jawab.

Pendidikan tidak hanya proses yang berlangsung di ruang kelas. Pendidikan olahraga atau yang bersifat fisik adalah bentuk pendidikan yang ditujukan untuk mendorong terbentuknya peserta didik yang sesuai dengan tujuan nasional. (Budi, Hidayat, \& Febriani, 2019) menjelaskan bahwa Pendidikan jasmani merupakan salah satu mata pelajaran yang wajib diikuti oleh siswa sebagai sarana bagi siswa untuk dapat mengembangkan potensi diri melalui berbagai aktifitas fisik. Lebih lanjut mengenai tujuan pendidikan jasmani, (Budi et al., 2019) menjelaskan bahwa Tujuan pendidikan jasmani tidak hanya untuk meningkatkan keterampilan siswa dalam bidang olahraga atau hanya untuk meningkatkan kebugaran jasmani peserta didik, akan tetapi pendidikan jasmani memiliki tujuan yang bersifat menyeluruh (holistik) yaitu mengembangkan kecerdasan secara kognitif, afektif dan psikomotor.

Tujuan pendidian jasmani dapat dicapai apabila dalam pembelajaran, guru mampu melaksanakan proses pembelaajran dengan tepat. Pada proses pembelajaran olahraga khususnya cabang olahraga sepakbola yang pada umumnya merupakan salah satu cabang olahraga yang banyak diminati oleh peserta didik. Proses pembelajaran bisa juga digunakanan sebagai proses pemasalan olahraga, karena melalui gerak dasar atau keterampilan gerak pada cabang olahraga bisa diletakkan, itulah kenapa pemasalan olahraga bisa menggunakan pembelajaran dalam pendidikan jasmani olahraga. Tetapi pada kenyataanya di dalam proses belajar berlangsung sebagian siswa belum mampu mencapai kompetensi individual yang diperlukan untuk teknik-teknik dasar sepak bola seperti shooting yang seharusnya dikuasai oleh setiap siswa sebagai dasar dari permainan cabang olahraga sepakbola, masih banyak siswa yang mengalami kesulitan untuk melakukan gerakan tersebut dengan benar.

(Sucipto, 2000) menjeaskan Ada tiga macam cara menendang yang umum dilakukan yaitu dengan punggung kaki, dengan bagian dalam kaki, dan dengan bagian luar kaki. Kualitas keterampilan teknik shooting bermain sepak bola sangat penting untuk dipelajari dan dilatih. (Luxbacher, 2012) Untuk 
mencetak gol pada gawang, anda harus mampu melakukan keterampilan menembak di bawah tekanan permainan akan waktu yang terbatas, ruang yang terikat, fisik yang lelah, dan lawan yang agresif. Makin baik tingkat penguasaan keterampilan teknik shooting pemainnya dalam memainkan dan menguasai bola, maka makin dekat pula dengan ketercapaian target kompetensi yang diharapkan.

Proses pembelajaran merupakan kunci utama dimana saat proses pembelajaran terjadi interaksi antara guru dengan peserta didik, bahan ajar disampaikan oleh guru dan diterima oleh peserta didik. Maka bahan ajar/isi pembelajaran disini merupakan pelantara terjadinya interaksi antara guru dan peserta didik, umpan balik yang terjadi dalam proses pembelajaran tersebut haruslah diteliti untuk dapat memperoleh gambaran penguasaan peserta didik pada bahan ajar yang disampaikan mulai dari perbedaan penguasaan teknik shooting sepak bola secara umum, hingga kecepatan daya serap siswa yang berbeda-beda. (Komarudin, 2015) menjelaskan Feed back (umpan balik) memegang peranan penting untuk meningkatkan peranan atlet, umpan balik diartikan sebagai informasi yang diterima oleh siswa mengenain performanya. Umpan balik apabila diberikan dengan baik dapat membantu siswa dalam mengatasi kesulitan belajar teknik dasar shooting sepak bola, umpan balik adalah perilaku guru untuk membantu setiap siswa yang mengalami kesulitan belajar secara individu dengan cara menanggapi hasil kerja siswa sehingga lebih menguasai materi yang disampaikan oleh guru.

Selain pentingnya merangkum hasil umpan balik yang dihasilkan dari proses pembelajaran, motivasi pada proses pembelajaran pun merupakan faktor pendukung yang memiliki arti penting bagi seorang peserta didik dalam upaya untuk membangkitkan semangat belajar bagi mereka. (Sadirman, 2014) Motivasi dapat dikatakan serangkaian usaha untuk menyediakan kondisi-kondisi tertentu, sehingga seseorang mau dan ingin melalukan sesuatu. Motivasi memegang peran penting dalam keberhasilan siswa melaksakan berbagai tugas gerak dalam pembelajaran penjas, khusunya teknik shooting dalam sepak bola. (Uno, 2011) menjelaskan peranan penting dari motivasi dalam belajar dan pembelajaran antara lain, a)menentukan hal-hal yang dapat menjadi penguat belajar, b) memperjelas tujuan yang hendak dicapai, c) menentukan ragam kendali terhadap ranngsangan belajar d) menentukan ketekunan belajar.

Hasil observasi terhadap hasil proses pembelajaran khusunya pada pembejaran sepakbola di SMAN 1 Kota Serang menunjukan bahwa hasil dan target pencapaian kompetensi masih kurang optimal. Hal ini dapat dilihat dari gerakan shooting terutama pada ketepatan serta daya shooting kuran optimal. Hasil observasi menunjukan bahwa kemampuan siswa untuk melakukan shooting secara tepat masih belum optimal. Bola yang di shooting terlalu menyimpang dari tujuan.

Teknik lain yang perlu diperbaiki adalah ketepatan menembak terutama sasaran dengan ruang yang sulit dijangkau oleh kiper misalnya pojok kiri atas. Sebagian besar para siswa memilih menembak berdasarkan keinginan dan kemudahan tembakan tanpa memperhatikan bagaimana kualitas tembakan. Seharusnya sebelum melakukan tembakan shooting pemain harus menghentikan bola terlebih dahulu agardapat menguasai bola sehingga dapat melakukanshooting yang terarah dan tepat pada sasaran. 
Pemain harus menghentikan bola terlebih dahulu agar dapat menguasai bola sehingga dapat melakukan shooting yang terarah dan tepat pada sasaran. Cara menghentikan bola masih lemah sehingga bola justru menyamping atau tidak dapat dihentikan secara sempurna karena posisi kaki tidak tepat yaitu tidak menggunakan kaki bagian dalam. seharusnya pada saat menghentikan bola gerakan kaki mengikuti bola ke belakang. Pada saat melakukan shooting perlu memperhatikan waktu yaitu pada saat melepaskan umpan. tidak terlalu cepat atau terlambat karena akan memberi peluang bagi lawan menutup pergerakan teman satu tim dan merebut bola tersebut.

Dari hasil pengamatan terhadap shooting diketahui bahwa cara menembak siswa belum sesuai dengan teknik menembak yang benar. Dilihat dari proses pembelajaran yang diterapkan dapat dilihat pelatih masih belum memperhatikan umpan balik yang timbul dari proses pembelajaran tersebut, mulai dari kesulitan-kesulitan gerakan,tingkat kecepatan pemahaman setiap individu, yang pada prosesnya mendukung tingkat penguasaan peserta didik terhadap bahan ajar. Pentingnya mendapatkan umpan balik dari peserta didik didalam proses pembelajaran untuk proses pembelajaran pada tahap-tahap selanjutnya maka tujuan tersebutlah yang menjadi fokus peneliti pembahasan dan keterkaitannya dengan penguasaan belajar keterampilan sepakbola.

\section{METODE}

Metode yang digunakan dalam penelitian ini adalah metode eksperimen. Metode eksperimen menilai pengaruh kondisi atau perlakuan (treatment) khusus terhadap variabel dependent. Pada penelitian ini menggunakan dua kelompok subjek yaitu kelompok eksperimen (experimental group) dan kelompok pengontrol (control group).Umpan balik yang digunakan adalah umpan balik eksperimen dengan desain faktorial $2 \times 2$ seperti terlihat pada tabel 3.1 di bawah ini

Tabel 1. Desai Faktorial $2 X 2$

\begin{tabular}{|c|c|c|c|}
\hline & Umpan Balik (A) & $\begin{array}{l}\text { Umpan balik } \\
\text { langsung }\left(\mathrm{A}_{1}\right)\end{array}$ & $\begin{array}{l}\text { Umpan balik } \\
\text { tertunda }\left(\mathrm{A}_{2}\right)\end{array}$ \\
\hline \multicolumn{4}{|l|}{ Variabel Atribut } \\
\hline $\begin{array}{l}\text { MotivasiTinggi (B1) } \\
\end{array}$ & & $\mathrm{A}_{1} \mathrm{~B}_{1}$ & $\mathrm{~A}_{2} \mathrm{~B}_{1}$ \\
\hline MotivasiRendah (B2) & & $\mathrm{A}_{1} \mathrm{~B}_{2}$ & $\mathrm{~A}_{2} \mathrm{~B}_{2}$ \\
\hline$\overline{\text { Total }}$ & & $\mathrm{A}_{1}$ & $\mathrm{~A}_{2}$ \\
\hline
\end{tabular}

Teknik pengambilan sampel yang digunakan mengacu pada prosedur yang dinyatakan oleh Verducci (1980) yaitu "menetapkan sampel dengan teknik persentase melalui pembagian dengan menggunakan system ranking $27 \%$ kelompok atas dan $27 \%$ kelompok bawah. Dalam penelitian ini 
adalah random sampling. Sedangkan sampel yang digunakan adalah siswa ektrakulikuler sepakbola SMAN 1 Kota serang yang diambil dari populasi terjangkau dan dikelompokkan berdasarkan tingkat motivasi latihan, motivasi latihan tinggi dan motivasi latihan rendah dijadikan landasan untuk mengelompokkan sampel kedalam eksperimen. Berdasarkan cara pembagian di atas dapat dikelompokkan sampel seperti tertera pada tabel di bawah ini :

Tabel 2. Pengelompokan Sampel Penelitian

\begin{tabular}{cccc} 
Langsung & Tertunda & $\begin{array}{c}\text { Total } \\
\text { Sampel }\end{array}$ \\
Tinggi (B1) & (A1) & (A2) & 16 \\
\hline Rendah (B2) & $(8)$ & A2B1 & $(8)$ \\
\hline Total Sampel & A1B2 & A2B2 & 16 \\
\hline
\end{tabular}

Pengolahan data dilakukan setelah data hasil penelitian diperoleh. Pengolahan data dilakukan berdasarkan umpan balik statistika agar diperoleh hasil perhitungan akhir atau kesimpulan yang benar bantuamn SPSS 20. dengan langkah-langkah sebagai berikut

1. Uji Normalitas yang digunakan pada penelitian ini adalah uji Shapiro-Wilk Test dengan taraf signifikansi $5 \%$ atau 0,05 .

2. Uji Homogenitas yang digunakan pada penelitian ini adalah uji Levane Statistic Test dengan taraf signifikansi $5 \%$ atau 0,05 .

3. Uji Hipotesis menggunakan Ujione way anova.

HASIL

Pengujian hipotesis dalam penelitian dilakukan dengan menggunakan analisis Variansi (ANAVA) dua jalur. Sebelum dilakukan analisis varians dua jalur, terlebih dahulu dilakukan uji prasyaratan analisis data yakni uji normalitas data dan homogenitas data.

1. Uji Normalitas Data

Uji normalitas pada penelitian ini dilakukan pada setiap kelompok teknik shooting sepakbola, baik kelompok yang diberi umpan balik langsung dan umpan balik tertunda, maupun kelompok yang memiliki motivasi tinggi dan rendah. Pengujian normalitas dilakukan dengan uji Liliefors, pada taraf 
signifikansi $[=0,05$. Dengan menggunakan program Excel for Windows 2013, diperoleh Lo dari delapan kelompok (A1, A2, A1B1,A1B2, A2B1, A2B2) tersebut lebih kecil dari Lt pada taraf signifikansi $\square=0,05$.

Dengan demikian dapat disimpulkan bahwa sampel penelitian berasal dari populasi yang berdistribusi normal. Hal ini memberikan petunjuk bahwa analisis statistik parametrik dapat digunakan dalam penelitian ini. Untuk lebih jelasnya kenormalan data tersebut, disajikan pada tabel berikut ini.

Tabel 3. Hasil Uji Normalitas Teknik Shooting Sepak Bola

\begin{tabular}{lllll}
\hline Kelompok Sampel & $N$ & Lo & $\mathrm{Lt}(\square=0,05)$ & Kesimpulan \\
\hline 1. A1 & 16 & 0,142 & 0,222 & Normal \\
2. A2 & 16 & 0,147 & 0,222 & Normal \\
3. A1B1 & 8 & 0,148 & 0,313 & Normal \\
4. A1B2 & 8 & 0,230 & 0,313 & Normal \\
5. A2B1 & 8 & 0,254 & 0,313 & Normal \\
6. A2B2 & 8 & 0,151 & 0,313 & Normal \\
\hline
\end{tabular}

Keterangan:

A1 = teknik shooting sepakbola yang diberikan umpan balik langsung

A2 = teknik shooting sepakbola yang diberikan umpan balik tertunda

A1B1 = teknik shooting sepakbola yang diberikan umpan balik langsung dengan motivasi tinggi.

A1B2 = teknik shooting sepakbola yang diberikan umpan balik langsung dengan motivasi rendah.

$\mathrm{A} 2 \mathrm{~B} 1=$ teknik shooting sepakbola yang diberikan umpan balik tertunda dengan motivasi tinggi.

A2B2 = teknik shooting sepakbola yang diberikan umpan balik tertunda dengan motivasi rendah.

\section{Uji Homogenitas Data}

Dalam penelitian ini uji homogenitas varians dilakukan terhadap: empat kelompok sel rancangan eksperimen antara teknik shooting sepakbola kelompok yang diberikan umpan balik langsung dengan motivasi tinggi (A1B1), teknik shooting sepakbola yang diberikan umpan balik langsung dengan motivasi rendah (A1B2), teknik shooting sepakbola yang diberikan umpan balik tertunda dengan motivasi tinggi (A2B1), dan teknik shooting sepakbola yang diberikan umpan balik tertunda dengan motivasi rendah (A2B2).

Uji homogenitas data teknik shooting sepakbola yang diberikan umpan balik langsung dengan motivasi tinggi (A1B1), teknik shooting sepakbola yang diberikan umpan balik langsung dengan motivasi rendah (A1B2), teknik shooting sepakbola yang diberikan umpan balik tertunda dengan motivasi tinggi (A2B1) dan teknik shooting sepakbola yang diberikan umpan balik tertunda dengan motivasi rendah (A2B2). Uji homogenitas varians keempat kelompok tersebut menggunakan uji Bartlett. Dengan menggunakan uji Bartlett diperoleh hasil perhitungan homogen seperti terangkum pada tabel berikut ini. 
Tabel 4. Hasil Uji Homogenitas Teknik Shooting Sepak Bola

\begin{tabular}{lllllll}
\hline Kelompok & Varians & $\begin{array}{l}\text { Varians } \\
\text { Gabungan }\end{array}$ & Harga B & X hit. & X gab & Ket. \\
\hline A1B1 & 106.79 & & & & & \\
A1B2 & 102.00 & & & & & \\
A2B1 & 96.79 & 98.96 & 55.87 & 0.054 & 7,81 & Homogen \\
A2B2 & 90.27 & & & & & \\
\hline
\end{tabular}

Berdasarkan data di atas dapat disimpulkan bahwa keempat kelompok data tersebut berasal dari populasi yang homogen. Diterimanya hasil uji normalitas dan homogenitas di atas, maka dapat disimpulkan bahwa uji persyaratan untuk pengujian hipotesis dengan analisis varians (ANAVA) dua jalur dapat dipenuhi dan dilaksanakan.

\section{Pengujian Hipotesis}

Setelah dilakukan uji persyaratan analisis dan hasil analisis perhitungan menunjukan bahwa sampel berasal dari distribusi normal dan homogen, selanjutkan dapat dilakukan uji hipotesis penelitian. Adapun data uji hipotesis penelitian ditampilkan pada tabel berikut ini:

Tabel 5. Deskripsi Data Uji Hipotesis

\begin{tabular}{|c|c|c|c|c|c|c|c|}
\hline $\begin{array}{l}\text { Adetede Latihan } \\
\text { Motivasi }\end{array}$ & \multicolumn{2}{|c|}{$\begin{array}{c}\text { Feedback } \\
\text { Langsung }\left(\mathrm{A}_{1}\right)\end{array}$} & \multicolumn{3}{|c|}{$\begin{array}{l}\text { Feedback Tertunda } \\
\qquad\left(\mathrm{A}_{2}\right)\end{array}$} & \multicolumn{2}{|l|}{ Total } \\
\hline \multirow{5}{*}{ Tinggi $\left(\mathrm{B}_{1}\right)$} & $\mathrm{n}$ & 8 & $\mathrm{n}$ & $=$ & 8 & $n_{b}$ & 16 \\
\hline & $\Sigma \mathrm{X}$ & $=1758$ & $\Sigma \mathrm{X}$ & $=$ & 1586 & $\Sigma X_{b}$ & $=3344$ \\
\hline & $\Sigma X^{2}$ & $=387068$ & $\Sigma X^{2}$ & $=$ & 315102 & $5 . x_{u}^{2}$ & $=702170$ \\
\hline & $\mathrm{x}$ & $=219.75$ & $\mathrm{x}$ & $=$ & 198.25 & $x_{b}$ & $=209.00$ \\
\hline & $(\Sigma X)^{2}$ & $=3090564$ & $(\Sigma X)^{2}$ & & 515396 & $\left(\Sigma X_{b}\right)^{2}$ & $=11182336$ \\
\hline \multirow{7}{*}{ Rendah (B2) } & $\mathrm{n}$ & $=$ & $n$ & $=$ & 8 & $\mathrm{n}_{\mathrm{b}}$ & 16 \\
\hline & $\Sigma x$ & 1644 & $\Sigma x$ & $=$ & 1685 & $\Sigma X_{b}$ & 3329 \\
\hline & $\Sigma x^{2}$ & $=338556$ & $\Sigma \mathrm{x}^{2}$ & $=$ & 355535 & $\Gamma \cdot x_{v}^{2}$ & $=694091$ \\
\hline & $x$ & $=205.50$ & $\mathrm{x}$ & $=$ & 210.63 & & $=208.06$ \\
\hline & $(\Sigma X)^{2}$ & $=2702736$ & $(\Sigma X)^{2}$ & $=$ & 2839225 & $\left(\Sigma X_{b}\right)^{2}$ & $=11082241$ \\
\hline & $n_{k}$ & 16 & $n_{k}$ & $=$ & 16 & $n_{t}$ & 32 \\
\hline & $\sum X_{k}$ & 3402 & $\sum \mathrm{X}_{\mathrm{k}}$ & $=$ & 3271 & $\sum \mathrm{X}_{\mathrm{t}}$ & 6673 \\
\hline \multirow[t]{3}{*}{ Total } & $\Sigma x_{i}^{2}$ & $=725624$ & $\Sigma x_{k}^{2}$ & $=$ & 670637 & $\Sigma x_{i}^{2}$ & $=1396261$ \\
\hline & $x_{k}$ & $=212.63$ & $x_{k}$ & $=$ & 204.44 & $x_{t}$ & $=208.53$ \\
\hline & $\left(\Sigma X_{k}\right)^{2}$ & $=11573604$ & $\left(\Sigma X_{k}\right)^{2}$ & $=$ & 10699441 & $\left(\Sigma X_{t}\right)^{2}$ & $=44528929$ \\
\hline
\end{tabular}


Berdasarkan tabel di atas tampak bahwa skor rata-rata A1B1 (219.75) > skor rata-rata A1B2 (198.25), dan skor rata-rata A2B1 $(205,50)$ < skor rata-rata A2B2 (208.06). Pengujian hipotesis penelitian ini dilakukan dengan teknik Analisis Varians dua jalur (ANAVA 2x2). Analisis variansi dua jalur adalah suatu teknik perhitungan (statistik parametrik) yang bertujuan untuk menyelidiki dua pengaruh, yaitu pengaruh utama (main effect) dan pengaruh interaksi (interaction effect). Pengaruh utamanya adalah pengaruh perbedaan umpan balik langsung dan umpan balik tertunda terhadap kemampuan kemampuan teknik shooting sepakbola. Pengaruh interaksi yang dimaksud adalah pengaruh interaksi antara metode umpan balik langsung dan metode umpan tertunda terhadap kemampuan kemampuan teknik shooting sepakbola ditinjau dari motivasi siswa. Adapun hasil perhitugan ANAVA 2 jalur, yaitu:

Tabel 6. analisi ANAVA Dua Jalur Kemampuan Kemampuan teknik shooting sepakbola

\begin{tabular}{lccllll}
\hline $\begin{array}{l}\text { Sumber } \\
\text { Variansi }\end{array}$ & \multirow{2}{*}{ Db } & \multirow{2}{*}{ JK } & RJK & \multirow{2}{*}{ Fhitung } & \multicolumn{2}{c}{ Ftabel } \\
\hline Antar Kolom & 1 & 536.28 & 536.28 & $5.419^{* *}$ & 4.20 & 0.01 \\
\hline Antar Baris & 1 & 7.03 & 7.03 & $0.071^{* *}$ & 4.20 & 7.64 \\
\hline Interaksi & 1 & 1417.78 & 1417.78 & $14.327^{* *}$ & 4.20 & 7.64 \\
\hline Dalam & 28 & 2770.88 & 98.96 & & & \\
\hline Total Direduksi & 31 & 4731.97 & & & & \\
\hline
\end{tabular}

Berdasarkan rangkungan perhitungan ANAVA 2 jalur pada Tabel 6, dapat disimpulkan hasil pengujian dari hipotesis 1 dan 2 sebagai berikut:

1) Hipotesis 1

Hipotesis alternatif $(\mathrm{Ha})$ yang menyatakan bahwa kemampuan teknik shooting sepakbola berbeda antara kelompok siswa yang belajar dengan metode umpan langsung dan umpan tertunda diterima, nilai Fhitung yaitu $5.419>$ Ftabel $=4,20$ (artinya menerima ha menolak ho ) sehingga dapat disimpulkan bahwa terdapat perbedaan yang signifikan antara umpan balik langsung dan umpan balik terhadap kemampuan kemampuan teknik shooting sepakbola. Artinya kemampuan teknik shooting sepakbola yang belajar dengan menggunakan metode langsung lebih tinggi dari siswa yang belajar dengan tertunda .

2) Hipotesis

Hipotesis alternatif $(\mathrm{Ha})$ yang menyatakan bahwa terdapat pengaruh interaksi antara umpan balik langsung dan motivasi belajar terhadap teknik shooting sepakbola diterima, nilai Fhitung $=14.327>$ Ftabel $=$ 4.20 (menerima ha menolak $\mathrm{HO}$ ) sehingga dapat disimpulkan bahwa terdapat interaksi yang signifikan antara umpan balik langsung dengan motivasi terhadap teknik shooting sepak bola. Bentuk interaksi tersebut dapat disajikan pada Gambar 1 di bawah ini. 


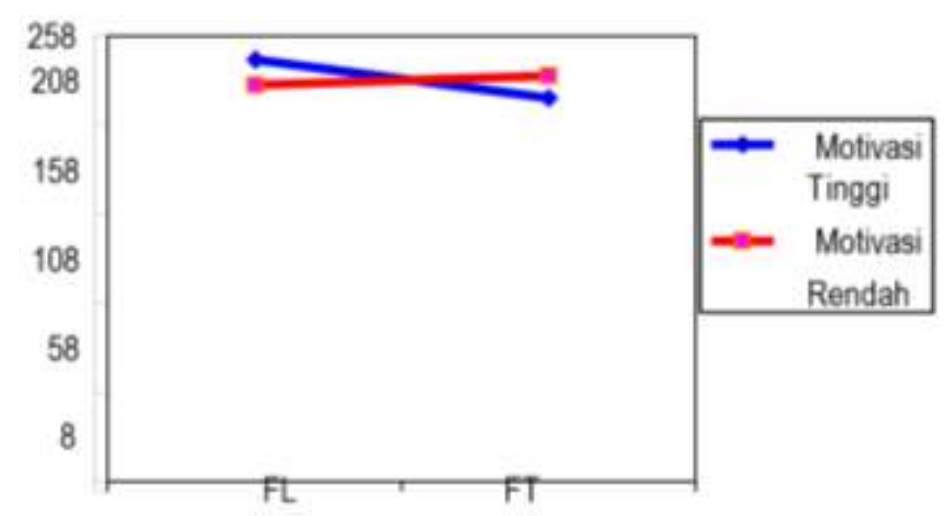

Gambar 1 Interaksi antara Feedback dan Motivasi

3) Hipotesis 3

Hipotesis alternatif $(\mathrm{Ha})$ yang menyatakan bahwa kemampuan teknik shooting sepakbola siswa yang memiliki motivasi tinggi dengan pembelajaran yang menerapkan umpan balik langsung lebih tinggi dibandingkan umpan balik tertunda diterima .nilai Fhitung $=0.071<$ Ftabel $=4.20$ (menolak ha menerima Ho) menunjukan bahwa tidak terdapat perbedaan signifikan kemampuan teknik antara peserta dengan motivasi tinggi dan peserta dengan motivasi rendah. Atau dengan kata lain kemampuan teknik yang memiliki motivasi tinggi dengan siswa yang memiliki motivasi rendah adalah sama.

\section{PEMBAHASAN}

Berdasarkan hasil perhitungan statistik inferensial, diketahui bahwa hipotesis penelitiannya diterima. Hasil perhitungan dapat dideskripsikan sebagai berikut:

\section{Perbedaan kemampuan kemampuan teknik shooting sepakbola antara siswa yang belajar dengan menggunakan umpan balik langsung dan siswa yang belajar dengan menggunakan umpan balik tertunda}

Keberhasilan Latihan teknik shooting sepakbola dalam kegiatan ekstrakulikuler adalah kegiatan yang dipengaruhi oleh faktor internal dan eksternal. Salah satu faktor yang mempengaruhi adalah penggunaan metode. Penggunaan metode didasarkan pada tujuan latihan. Metode yang digunakan untuk memfasilitasi para siswa berinteraksi dengan sumber belajar yaitu umpan balik langsung maupun tidak langsung.

Hasil penelitian menunjukan bahwa terdapat perbedaan antara signifikan antara umpan balik langsung dengan tidak langsung terhadap teknik shooting sepakbola. Para siswa yang berlatih dengan menggunakan umpan balik langsung memiliki hasil tes yang lebih tinggi dibandingkan dengan siswa yang menggunakan umpan balik tertunda baik kelompok motivasi tinggi maupun motivasi rendah. 
Hal ini menunjukan bahwa penggunaan umpan balik langsung mempengaruhi bagaimana para siswa memperoleh pengetahuan, memperoleh pemahaman tentang teori dalam melakukan shooting. Para siswa yang memperoleh feedback langsung dapat menerapkan pengetahuan tersebut dan melakukan evaluasi terhadap kemampuannya dalam melakukan shooting. Para siswa belajar lebih cepat untuk menilai dan menyimpulkan mengenai kemampuannya sendiri dan melakukan evaluasi untuk perbaikan teknik. Para siswa yang memperoleh feedback langsung lebih menerima, lebih cepat menanggapi serta mengatur diri untuk memperbaiki kesalahannya dan menjadikan apa yang diinformasikan oleh pelatiha sebagai panduan untuk memperbaiki kemampuan teknik shooting. Para siswa yang memperoleh feedback langsung akan lebih responsif terhadap perbaikan yang disampaikan oleh pelatih.

Feedback langsung yang diterima siswa lebih mudah diterima karena para siswa masih mengingat apa kesalahannya maupun bagaimana mengabstraksikan gerakan-gerakan yang didemonstrasikan oleh pelatih kemudian membandingkan dengan kemampuannya sendiri. Feedback langsung memungkinkan para siswa untuk memperbaiki persepsinya tentang teknik sepakbola, lebih siap untuk melakukan perbaikan, memiliki kesempatan untuk melakukan gerakan teknik shooting lebih tepat dengan adanya bimbingan. Dengan adanya feedback langsung para siswa lebih terarah untuk melakukan gerakan teknik shooting secara mekanistik dan kemudian menjadi gerakan-gerakan yang biasa dilakukan meskipun gerakan tersebut cukup kompleks.

Hasil penelitian sejalan dengan penelitian yang dilakukan oleh Anna Rowe yang menunjukan bahwa feedback tidak hanya meningkatkan hasil belajar, Feedback mempengaruhi bagaimana konsepsi peserta didik terhadap manfaat feedback itu sendiri dalam proses pembelajaran (Rowe, 2010). Para siswa yang memperoleh feedback umum di dalam kelas sering merasa bosan dan jenuh serta mengalami kesulitan untuk memberikan fokus. Berbeda dengan feedback langsung yang dianggap lebih spesifik, objektif, mudah diingat ( pengalaman langsung) terutama bagi para iswa yang memiliki pengalaman rendah dalam melakukan kegiatan sepakbola dan kurang menguasai teknik sepakbola.

\section{Terdapat pengaruh interaksi antara umpan balik dan motivasi terhadap kemampuan kemampuan teknik shooting sepakbola}

Siswa yang memperoleh umpan balik langsung terutama pada kelompok motivasi tinggi memiliki skor yang lebih tinggi dibandingkan kelompok lain. Hasil penelitian menunjukan adanya interaksi antara metode umpan balik dengan motivasi. Hasil penelitian sejalan dengan penelitian yang dilakukan oleh Anna Rowe bahwa feedback langsung meningkatkan motivasi belajar. Para siswa merasa termotivasi dengan adanya feedback langsung dan mendorong para siswa tertarik terhadap hasil belajarnya maupun kemajuannya.

Siswa yang termotivasi tinggi akan semakin termotivasi untuk mengetahui lebih banyak, memahami lebih luas serta lebih menerima dan menanggapi apa yang disampaikan oleh pelatih. Hasil dari 
meningkatnya pengetahuan, penerimaan maupun tanggapan langsung yang disampaikan pelatih dapat dilihat dari kemampuan siswa dalam mempraktekan shooting.

Hasil penelitian sejaklan dengan barbara Rhoads dkk yang melakukan penelitian terhadap pengaruh feedback melalui video dan verbal terhadap performance siswa dalam pembelajaran motorik. Hasil penelitian menunjukan bahwa feedback secar verbal ( tradisional) kepada siswa memiliki pengaruh terhadap performance siswa (Michael 2010) ditegaskan bahwa feedback melalui visual hanya memberikan pengaruh sedikit.

3. Pada kelompok siswa yang memiliki motivasi tinggi, kemampuan teknik shooting sepakbola yang belajar menggunakan umpan balik langsung lebih tinggi dari siswa yang belajar menggunakan umpan balik tertunda

Siswa yang termotivasi memiliki dorongan kuat, lebih terarah, dan memiliki daya tahan dalam menghadapi kesulitan untuk memperoleh kemajuan dalam belajarnya. para siswa yang termotivasi lebih terlibat dalam proses pembelajaran terlebih dengan adanya feedback langsung dari para pelatih. Jumlah perilaku (teknik shooting) yang dilakukan berulang sebagai hasil feedback langsung pada kelompok motivasi tinggi lebih banyak dibandingkan dengan kelompok lain terlebih dengan adanya feedback langsung dimana para siswa memiliki kesempatan untuk memperbaikinya. Praktek-praktek siswa yang memiliki motivasi tinggi lebih kuat dan intens dibandingkan dengan kelompok siswa yang kurang termotivasi.

Informasi langsung yang diperoleh siswa yang termotivasi akan lebih kuat disimpan dalam memorinya dan secara tepat diinterpretasikan memori tersebut termasuk informasi langung dari pektaih dalam bentuk praktek teknik yang benar. informasi yang disampaikan oleh tutor harus sesuai dengan konsep teori karena ketidaksesuian akan menimbulkan penolakan dari siswa. siswa yang termotivasi memiliki orientasi tinggi terhadap penggunaan feedback yang tepat untuk memperbaiki kemampuannya. Hasil penelitian ini sejalan dengan hasil penelitian Barbara walsh yang menjelaskan berdasarkan hasil penelitiannya bahwa umpan balik harus memfasilitasi proses belajar menjadi lebih mudah (Walsh, 2015)

4. Pada kelompok siswa yang memiliki motivasi diri rendah, kemampuan teknik shooting sepakbola yang belajar menggunakan metode umpan balik langsung lebih tinggi dari siswa yang belajar menggunakan umpan balik tertunda

Hasil penelitian menunjukan bahwa para siswa yang diberikan umpan balik langsung berbeda dengan siswa yang dilatih dengan metode feedback tertunda. Perbedaan motivasi itu sendiri mempengaruhi bagaimana hasil belajar siswa. Para siswa yang memiliki motivasi rendah cenderung memiliki penurunan hasil dibandingkan dengan siswa yang memiliki motivasi tinggi meskipun diberikan feedback tertunda. Hasil ini sejalan dengan penelitian yang dilakukan oleh Anna Rowe seperti disampaikan bahwa motivasi yang berbeda akan mempengaruhi respon siswa individu untuk umpan balik dalam 
berbagai cara. Feedback tertunda akan mempengaruhi bagaimana respon siswa yang memiliki motivasi rendah untuk memperbaiki kemampuan tekniknya.

Siswa yang memiliki motivasi rendah dengan feedback tertunda cenderung memberikan respon negatif artinya tidak menanggapi apa yang disampaikan oleh pelatih. Para siswa memiliki keterbatasan dalam mengingat tindakannya pada mempraktekan teknik shooting terlebih bagi para siswa yang kurang memiliki intensitas, daya tahan dan yang kurang terarah pada tujuan. Siswa yang memiliki motivasi rendah memberikan hambatan psikologis agar tidak terlibat dalam kegiatan latihan seperti tidak memperhatikan atau bercanda. Para siswa sulit menarik memori atau ingatannya pada saat berlatih karena tidak membutuhkan pentingnya memperhatikan feedback dari pelatih. Supaya hasil belajar teknik shooting optimal maka perlu diberikan penyajian materi dimana siswa terdorong untuk mengasosiasikannya dengan pengalaman melakukan shooting.

Adanya motivasi mempengaruhi hasil teknik sepakbola yang dimilikinya sebagai hasil belajar. Adanya feedback tertunda atau langsung akan mempengaruhi bagaimana motivasi siswa dalam mengikuti fase pembelajaran dan pada akhirnya mempengaruhi bagaimana hasil belajar teknik sepakbola tersebut. Para siswa yang memiliki motivasi rendah cenderung memberikan respon rendah atau kurang berusaha untuk mengkonstruksi pengetahuan, pemahaman maupun kemampuannya mempraktekan teknik shooting yang benar.Para siswa yang memilik motivasi rendah kurang memiliki penguatan-penguatan dalam dirinya untuk mengingat, menerima dan kurang siap melakukan gerakan-gerakan shooting yang kompleks. Sehingga hasilnya siswa yang memiliki motivasi rendah dengan feedback langsung lebih tinggi kemampuan teknik shooting sepakbola dibandingkan yang diberikan feedback tertunda.

\section{SIMPULAN}

Berdasarkan hasil uraian yang telah dikemukakan sebelumnya dan dalam batasan-batasan penelitian ini maka hasil pengujian hipotesis dapat ditarik kesimpulan sebagai berikut.

1. Metode umpan balik langsung lebih baik dibandingkan dengan metode pemberian umpan balik tertunda terhadap hasil belajar shooting dan passing karena ada perbedaan yang signifikan. Metode umpan balik langsung memberikan kesempatan kepada siswa untuk memperoleh informasi yang secara langsung akan dihubungkan dengan kemampuannya saat ini. Para siswa lebih mudah mengingat kemampuannya dan lebih mudah membandingkan dengan feedback sehingga memperkuat keyakinannya dan mengarahkannya pada kemampuan teknik yang lebih baik.

2. Terdapat Interaksi antara pemberian feedback dan motivasi terhadap kemampuan teknik shooting dan passing siswa peserta kegiatan ekstrakulikuler Secara keseluruhan dari perhitungan statistic dapat disimpulkan, ada perbedaan yang signifikan antar kelompok penelitian.

3. Bagi siswa yang memiliki motivasi tinggi, pemberian umpan balik langsung lebih baik dibandingkan 
dengan metode pemberian umpan balik tertunda terhadap kemampuan teknik karena tidak perbedaan yang signifikan.

4. Pada siswa yang memiliki motivasi rendah, pemberian umpan balik langsung lebih baik dibandingkan dengan metode pemberian umpan balik tertunda terhadap kemampuan teknik karena dengan umpan balik langsung siswa yang memiliki motivasi rendah masih lebih memahami dibandingkan dengan umpan balik tertunda,

\section{REFERENSI}

Budi, D. R., Hidayat, R., \& Febriani, A. R. (2019). The Application of Tactical Approaches in Learning Handballs. JUARA : Jurnal Olahraga. https://doi.org/10.33222/juara.v4i2.534

Komarudin, K. (2015). Psikologi Olahraga. Bandung: Remaja Rosdakarya.

Luxbacher, A. J. (2012). Sepak Bola. Jakarta: Raja Grafindo Persada.

Sadirman. (2014). Interaksi Dan Motivasi Belajar Mengajar. Jakarta: Bumi Aksara.

Sucipto, dkk. (2000). Sepakbola. Bandung: FPOK UPI.

Uno, H. (2011). Metode Pembelajaran. Jakarta: BumiAksar. 